\title{
IDENTIFICATION AND SCREENING OF NEW GENERATION INSECTICIDES AGAINST CARDAMOM THRIPS (SCIOTHRIPS CARDAMOMI ) IN CARDAMOM CULTIVATIONS IN SRI LANKA
}

\author{
M. Dharmadasa*, T. Nagalingam and P.H.M. Seneviratne \\ Research Station, Department of Export Agriculture, Matale, Sri Lanka \\ Accepted 21 October 2008
}

\begin{abstract}
Two thrips species were identified from cardamom (Elettaria cardamomum) cultivations in Sri Lanka. They are the cardamom leaf thrips, Panchaetothrips indicus Bagnall (1912) and the cardamom thrips, Sciothrips cardamomi (Ramakrishna, 1935). Sciothrips cardamomi collected from Nuwara Eliya district is emerging as a devastating pest of cardamom (Elettaria cardamomum) in the district. Both adults and larvae damage panicles, flowers and capsules of cardamom. Injury to panicles leads to stunted growth, and damaged flowers fall prematurely. Affected tender capsules show scabby growth on the surface as they mature and hence have no market value. To manage this problem and as an immediate control measure, damage causing thrips were identified, damage estimated and seven new generation insecticides were screened at Kabragala Estate in Elamulla, Nuwara Eliya.

The estimated direct pod damage was $91.7 \pm 3.2 \%$. Severely damaged pods showed significantly lower pod weight than undamaged pods. No significant difference in the pod weight was observed between undamaged pods and pods with less than $2 / 3$ of scabby area. The insecticides Actara (thiamethoxam), Match (lufenuron), Regent (fipronil) and Calypso (thiacloprid) successfully reduced the pod damage while Matric (chromafenozide), Mimic (tebufenozide) and Mospilan (acetamiprid) did not reduce the damage percentage. But higher yields of 335.54 and $304.98 \mathrm{~g} / \mathrm{bush} /$ harvest were obtained from the plots treated with Actara or Match respectively, in comparison to all other treatments. Therefore, either Actara or Match could be recommended for the management of $S$. cardamomi in cardamom plantations.
\end{abstract}

Key words: Sciothrips cardamomi, Panchaetothrips indicus, Elettaria cardamomum

\section{INTRODUCTION}

Cardamom, Elettaria cardamomum (L.) (Zingiberaceae), a perennial herbaceous spice has been grown under forest cover as a plantation crop, in the mid country and up country wet zones of Sri Lanka, for more than two centuries. Until recently, there were no serious pest problems except by the cardamom stem and capsule borer Dichocrocis punctiferalis (Guen.) which has been kept under control through Integrated Pest Management (IPM). Until recently, thrips were not important pests of cardamom in Sri Lanka. However, after the introduction of the high yielding cultivar (Green gold) in 2001 from India to Kabaragala Estate, Elamulla, Nuwara Eliya, thrips emerged as a severe pest causing $60-90 \%$ of pod damage.

The cardamom thrips, Sciothrips cardamomi (Ramk.) and cardamom leaf thrips, Panchaetothrips indicus Bagnall have been recorded from cardamom in Sri Lanka (Anon,
1992). Panchaetothrips indicus was reported as a pest of turmeric, Curcuma domestica in India (Bagnall, 1912). This species has been reported from Sri Lanka as a pest of ginger, Zingiber officinale (Wijeratne, 1999). Panchaetothrips indicus is a sap sucking pest of foliage. Larvae are gregarious in nature and feed on the upper surface of young cardamom leaves. Infested leaves roll upwards, turn yellow and later dry up. Following severe infestation, young plants die. The adult thrips are black in colour and a characteristic feature is that they keep their abdomen turned upwards in a bent position (Singh and Kumaresan, 1996).

An outbreak of $P$. indicus had been observed in cardamom plantations in the Kandy District in 1986 during the dry seasons but did not cause severe yield loss. Recently this pest appeared in a cardamom nursery in Walpita in the Gampaha District. Damage by $P$. indicus is not common in cardamom growing areas and no particular control measures are needed.

*Corresponding author's email:maduradh@yahoo.co.nz 


\section{Biology of Sciothrips cardamomi}

The first report of S. cardamomi is from South India (Ramakrishna Ayyar and Kylasam, 1935) from cardamom. They reported severe damage on cardamom pods.

Thrips colonize and breed in unopened leaves, leaf sheath, spindles, flower bracts, perianths and flower tubes of cardamom. Adults and larvae cause damage to panicles, flowers and capsules. It lacerates the surface tissues with its mandibles and sucks plant sap. Injury to panicles results in stunted growth, and on flowers leads to flower dropping. Injuries to tender capsules produce a scabby growth on capsules as they mature (Fig. 1). Damaged capsules appear malformed, shriveled and sometime have gaping slits. Such capsules have no export value, are inferior in aroma, have lesser number of seeds, underdeveloped seeds and poor seed germination.

The adult thrips is grayish brown in colour, $1.25-1.5 \mathrm{~mm}$ long and with two pairs of fringed wings. Females lay eggs singly in an incision made in plant tissue by the ovipositor. Eggs hatch and larvae emerge in 12 days. Larvae feed on plant sap. They pass through three larval and a pupal stage and become adults, thus completing the life cycle in $21-32$ days. Populations are high in dry periods and low in rainy periods (Sing et al., 1999). Only organophosphate insecticides have been recommended in India where thrips damage occurs severely (Anon, 2001). This study was carried out to identify the thrips species on cardamom, to estimate the severity of damage, and to screen new generation insecticides to control the cardamom thrips.

\section{MATERIALS AND METHODS}

\section{Identification of thrips}

Thrips were collected from cardamom plants in Nuwara Eliya, Gampaha and Matale districts of Sri Lanka. They were stored in 70\% ethanol. Slide mounted specimens were observed under the microscope and identification of thrips was made by Ms. K. Tillekaratne of the Department of Zoology, Faculty of Science, University of Peradeniya.

\section{Damage severity and screening of insecticides}

Insecticide trials were carried out at Kabaragala Estate Elamulla in the Nuwara Eliya District where cardamom has been grown for more than 100 years. This plantation is located in the Upcountry Wet Zone (WU2) and it is one of the well managed cardamom plantations in the country.

\section{Estimation of damage severity}

At the beginning of the treatment trial (before treatment applications), mature pods were harvested from randomly selected five cardamom plants and the pods were graded into four groups based on the scabby area on the pods. The four groups were;

1. no scabby formation

2. scabby patches on pods cover less than $1 / 3$ of the pod

3. scabby patches on pods cover more than $1 / 3$ but less than $2 / 3$ of the pod

4. scabby area covers more than $2 / 3$ of the pod

\section{Screening of insecticides}

Seven new generation insecticides, mainly neonicotinoids were compared with the nonsprayed control to find a suitable insecticide for the control of the pest (Table 1).

A five year old cardamom block was selected for the study. Spacing of plants was $2.5 \times 2.0 \mathrm{~m}$ and the cultivated variety was Green Gold which was imported from India. Treatment application was carried out in randomized complete block design with three replicates and the number of plants per plot was four. There were two cardamom rows as guard rows in between each treatment plot. Initial application of treatments was done in July 2006 and six rounds of treatment applications were carried out at monthly intervals. Pods were harvested at maturity and yield data were recorded. Numbers of damaged and undamaged pods were recorded at each harvest by obtaining a sample from each bush.

Yield and percentage of damaged pods were subjected to analysis of variance (ANOVA). Percentage data were transformed to inverse sine before analyses were carried out. 

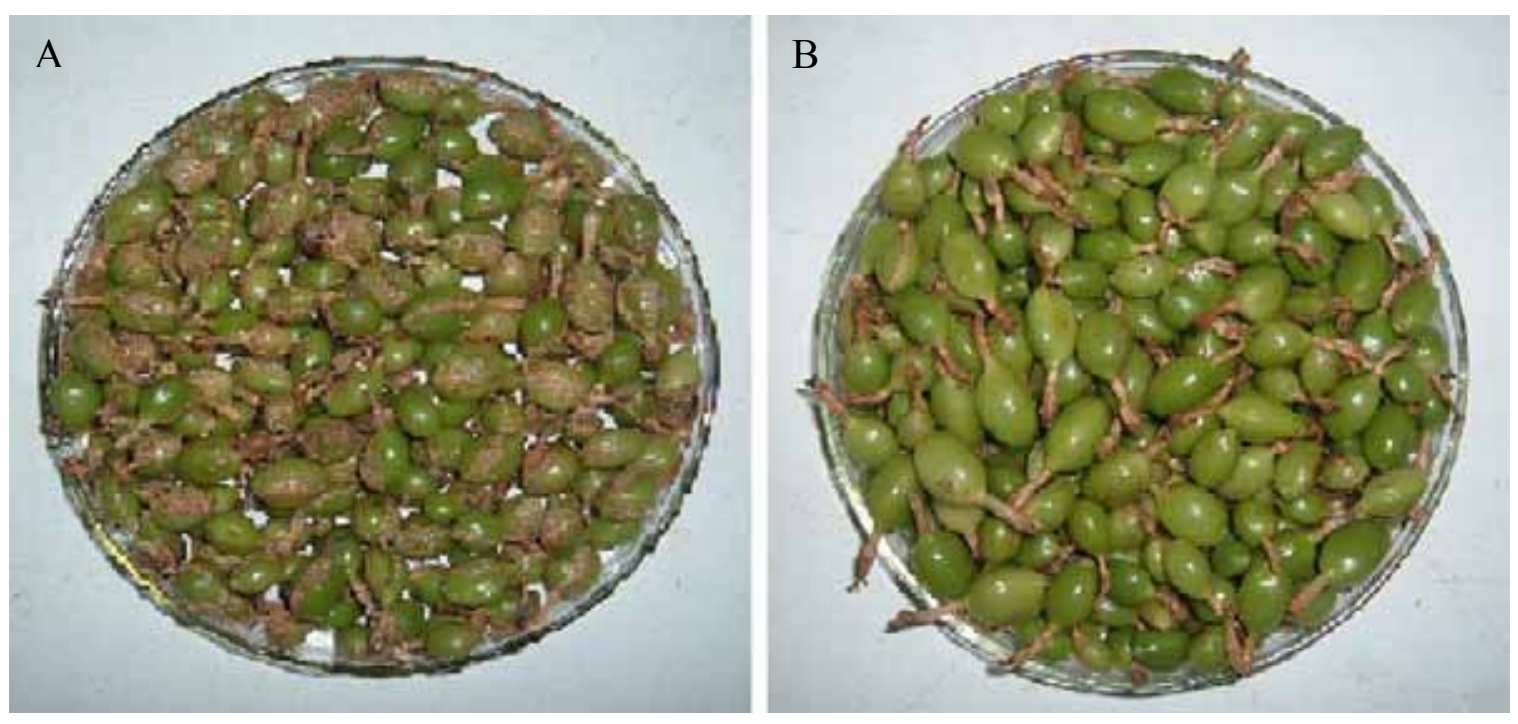

Figure 1. Cardamom pods damaged by cardamom thrips (Sciothrips cardamomi) (A) and undamaged pods (B).

Table 1. Insecticides tested against Sciothrips cardamomi.

\begin{tabular}{|c|c|c|}
\hline Treatment & Mode of action & Application rate \\
\hline 1. Control & - & - \\
\hline 2. Regent 50SC (fipronil $5 \mathrm{~g} / \mathrm{L} \mathrm{SC}$ ) & $\begin{array}{l}\text { Potent blocker of GABA regulated } \\
\text { chloride channel }\end{array}$ & $4 \mathrm{ml} / 10 \mathrm{~L}$ \\
\hline 3. Match 50EC ( lufenuron $50 \mathrm{~g} / \mathrm{L} \mathrm{EC}$ ) & Inhibit chitin synthesis & $10 \mathrm{ml} / 10 \mathrm{~L}$ \\
\hline 4. Matric $5 \%$ SC (chromafenozide $50 \mathrm{~g} / \mathrm{L} \mathrm{SC}$ ) & Inhibit insect molting & $9 \mathrm{ml} / 10 \mathrm{~L}$ \\
\hline 5. Calypso SC 240 (thiacloprid $240 \mathrm{~g} / \mathrm{L}$ SC) & Agonist of acetylcholine receptors & $8 \mathrm{ml} / 10 \mathrm{~L}$ \\
\hline 6. Mimic 20F (tebufenozide $200 \mathrm{~g} / 1 \mathrm{SC}$ ) & Inhibit insect molting & $15 \mathrm{ml} / 10 \mathrm{~L}$ \\
\hline 7. Mospilan 20SP (acetamiprid 20\% SP) & Agonist of acetylcholine receptors & $5 \mathrm{~g} / 10 \mathrm{~L}$ \\
\hline 8. Actara $25 \mathrm{WG}$ (thiamethoxam $25 \% \mathrm{WG}$ ) & Agonist of acetylcholine receptors & $5 \mathrm{~g} / 10 \mathrm{~L}$ \\
\hline
\end{tabular}

\section{RESULTS}

\section{Identification of thrips}

The specimens collected from Nuwara Eliya District were identified as thrips, Sciothrips cardamomi (Ramk.) by Ms. K. Tillekaratne of the Department of Zoology, Faculty of Science, University of Peradeniya. This species was not found in any of the other cardamom growing areas. Cardamom leaf thrips, Panchaetothrips indicus was found in other cardamom growing areas and also in Nuwara Eliya district.

\section{Estimation of damage severity}

Of the pods examined, $91.7 \pm 3.2 \%$ showed scabby formation where as only $8.9 \%$ of the pods showed no scabs. Undamaged pods showed significantly $(\mathrm{p} \geq 0.001)$ higher pod weight $(0.112$ $\mathrm{g} / \mathrm{pod})$ than severely damaged pods $(0.063$ $\mathrm{g} /$ pod). No significant difference in pod weight was observed between undamaged pods and pods with less than $2 / 3$ of scabby area (Table 2 ). When pods showed more than $2 / 3$ of scabby formation, pod weight was $50 \%$ lower compared to undamaged pods. 
Table 2 Effect of Sciothrips cardamomi damage on cardamom pod weight.

\begin{tabular}{lc}
\hline Damage level & Mean weight of pod $(\mathrm{g})$ \\
\hline No damage (no scabby formation) & $0.112 \mathrm{a}$ \\
Scabby area less than $1 / 3$ of pod & $0.097 \mathrm{a}$ \\
Scabby area more than $1 / 3$ and less than $2 / 3$ of pod & $0.092 \mathrm{a}$ \\
Scabby area more than $2 / 3$ of the pod & $0.063 \mathrm{~b}$ \\
\hline
\end{tabular}

No. of pods $(\mathrm{n})=653$

Means followed by the same letter are not significantly different at $\mathrm{p} \geq 0.05$

Table 3. Effect of insecticide treatment on pod damage by Sciothrips cardamomi and yield of cardamom.

\begin{tabular}{|c|c|c|}
\hline Treatment & $\%$ pod damage due to thrips & Mean yield $(\mathrm{g}) / \mathrm{bush}$ \\
\hline Control & $63.20 \mathrm{~b}$ & $185.50 \mathrm{~d}$ \\
\hline Matric 5\% SC (chromafenozide 50g/L SC) & $83.70 \mathrm{a}$ & $219.31 \mathrm{dc}$ \\
\hline Mimic 20F (tebufenozide 200g/1SC) & $61.94 b$ & $153.24 d$ \\
\hline Mospilan 20SP (acetamiprid 20\% SP) & $53.46 \mathrm{bc}$ & $216.41 \mathrm{dc}$ \\
\hline Match 50EC (lufenuron $50 \mathrm{~g} / \mathrm{L} \mathrm{EC}$ ) & $44.96 \mathrm{c}$ & $304.98 \mathrm{ab}$ \\
\hline Calypso SC 240 (thiacloprid 240g/L SC) & $43.91 \mathrm{c}$ & $161.47 \mathrm{~d}$ \\
\hline Actara25WG (thiamethoxam 25\% WG) & $43.40 \mathrm{c}$ & $335.54 a$ \\
\hline Regent 50SC (fipronil 5g/L SC) & $42.75 \mathrm{c}$ & $262.99 \mathrm{bc}$ \\
\hline LSD & 11.99 & 62.67 \\
\hline
\end{tabular}

Means followed by the same letter are not significantly different at $p \geq 0.05$

\section{Screening of insecticides against cardamom thrips}

Significantly lower $(\mathrm{p} \geq 0.001)$ percentage of pod damage was observed when treated with Match, Calypso, Actara and Regent compared to Matric, Mimic, Mospilan and the control (Table 3). Bushes treated with Matric had the highest percentage of pod damage, significantly higher $(\mathrm{p} \geq 0.001)$ than the control treatment. Also significantly higher $\quad(\mathrm{p} \geq 0.001)$ yields were obtained from bushes treated with Actara, Match and Regent, than with Calypso, Mimic or the control. Even though, application of Calypso reduced the damage levels (as with Actara,) it did not increase the yield when compared to the control. Actara and Match produced the highest yield (335.54 and $304.98 \mathrm{~g} / \mathrm{bush} / \mathrm{harvest}$ ). These findings confirm that thrips damage not only produces a reduction in quality of pods through its scabby formation but also a significant reduction in pod yield.

\section{DISCUSSION}

The cardamom thrips, S. cardamomi found in Nuwara Eliya is emerging as a devastating pest of cardamom (Elettaria cardamomum) in Sri Lanka. Damage by leaf thrips on the other hand does not bring about any economic loss to the crop. It is found only during dry seasons and with the rains the damage disappears.

In thrips infested cardamom fields, where more than $90 \%$ of pod damage was observed the pods with scabs have no export value. A study conducted in Karnataka, India, during 2001 2002 to estimate losses caused by thrips (Sciothrips cardamomi) in cardamom, (Thyagaraj et al., 2003) reported $15.84 \%$ damage to cardamom capsules. In comparison the severity of the problem in Sri Lanka is much higher and needs urgent proper control methods for the pest. 
Insecticidal treatments with Matric resulted in higher percent pod damage than in the control. This may be due to the adverse effects of the chemical on the natural enemy population, even though we could not confirm it due to unavailability of relevant data.

The study reveals a greater economic loss due to scabby formation and lower pod weight following thrips damage in additon to the direct yield loss. Several insecticides have been tested for cardamom thrips in India (Rajkumar et al., 2003; Thyagaraj et al., 2002; Gopakumar and Chandrasekar, 1998; Gopakumar and Singh, 1996) but majority of them are either organophosphate or botanicals. In Sri Lanka, application of organophosphate insecticides is not encouraged by the government. This is the first record of use of insecticides in neonicotinoid group against cardamom thrips.

The study further confirms that insecticide treatments that resulted in lower percentage of pod damage produced higher yields. This may be due to the suppression of thrips population and the subsequent lowering of panicle and flower shedding.

As application of Actara and Match reduced scabby formation on pods and also produced higher yield than untreated bushes, these two insecticides could be recommended in order to have a higher yield with more exportable quality cardamom.

\section{ACKNOWLEDGEMENTS}

The authors thank Prof. J.P. Edirisinghe and Ms. K Thilakaratne, Department of Zoology, Faculty of Science, University of Peradeniya for the identification of thrips specimens and $\mathrm{Mr}$. Janalal Rodrigo, the Director of the P.W. Rodrigo Estate Limited, Kabaragala Estate, Elamulla for providing land and labour for the field study.

\section{REFERENCES}

Anon (1980). Cardamom Culture. Spice board, Ministry of Commerce and Industry, Government of India. Cochin, India.

Anon (1992). Insect pests of Export Agriculture Crops, Department of Export Agriculture, Peradeniya.
Anon (2001). Cardamom package of practice. Spice board, Ministry of Commerce and Industry, Government of India. Cochin, India.

Bagnall, R.S. (1912). A new genus of Indian thrips (Thysanoptera) Injuries to turmeric. Record of the Indian Museum 7: 257-260.

Gopakumar, B. and Chandrasekar, S.S. (1998). Evaluation of two new formulations of quinalphos against cardamom thrips, Sciothrips cardamomi (Ramk). Developments in plantation crops research. Proceedings of the $12^{\text {th }}$ Symposium on Plantation Crops. PLACROSYM-XII, Kottayam, India. Pp. 273275.

Gopakumar, B., Singh, J. (1996). Evaluation of neem insecticides against cardamom thrips Sciothrips cardamomi. Allelopathy in pests management for sustainable agriculture. Proceedings of the Internationa Conference on Allelopathy 2: 197-200.

Rajkumar, A.J. Kurian, P.S. Backiyarani, S. Murugan, M. (2003). Evaluation of biorationals against thrips (Sciothrips cardamomi Ramk.) and shoot and capsule borer (Conogethes punctiferalis Guen.) in cardamom. Journal of Spices and Aromatic Crops 11: 132-134.

Ramakrishna, Ayyar, T.V. and Kylasam, M.S. (1935). A new disease of cardamom (Elattaria cardamom) apparently due to insect damage in South India, Bulletin of Entomological Research 26: 359-361.

Singh, J. and Kumaresan, D. (1996). A note on small cardamom (Elettaria cardamomum Maton) leaf thrips, Panchaetothrips indicus Bagnall (Thysanoptera: Thripidae). Journal of Entomological Research 20: 379-381.

Singh, J., Sudharshan, M.R. and Selvan, M.T. (1999). Seasonal population of cardamom thrips (Sciothrips cardamomi (Ramk.) on three cultivar types of cardamom (Elettaria cardamomum Maton). Journal of Spices and Aromatic Crops 8: $19-22$.

Thyagaraj, N.E., Singh, P.K. and Chakravarthy, A.K. (2002). Effect of plant based insecticides on cardamom thrips Sciothrips cardamomi (Ramk.) and shoot and fruit borer Conogethes punctiferalis (Guenee) infestation. Insect Environment 7: 179-180. 
Thyagaraj, N.E., Singh, P.K. and Chakravarthy, A.K. (2003). Estimation of loss caused by thrips (Sciothrips cardamomi Rmk.) in cardamom (Elettaria cardamomum Maton). Pest Management in Horticultural Ecosystems 9: 55-57.
Trevor Lewis (1973). Thrips, Their biology, ecology and economic importance. Academic press, London and New York. Pp. 349.

Wijeratne, P.M. (1999). Insects feeding on plants in Sri Lanka, Department of Agriculture, Ministry of Agriculture and Lands, Sri Lanka. Pp. 171. 